\title{
The effect of polyethylene glycol (PEG 8000) supplementation on in vitro gas production kinetics of leaves from tannin containing trees
}

\author{
A. Kamalak ${ }^{1 \#}$, O. Canbolat ${ }^{2}$, M. Sahin ${ }^{1}$, Y. Gurbuz ${ }^{1}$, E. Ozkose ${ }^{1}$ and C.O. Ozkan ${ }^{1}$ \\ ${ }^{1}$ Kahramanmaras Sutcu, Imam University, Faculty of Agriculture, Department of Animal Science, \\ 46100 Kahramanmaras, Turkey \\ ${ }^{2}$ Bursa Uludag University, Faculty of Agriculture, Department of Animal Science, Bursa, Turkey
}

\begin{abstract}
The objective of this study was to determine the effect of inclusion of polyethylene glycol (PEG 8000) during in vitro incubation on gas production kinetics, organic matter digestibility (OMD) and the metabolisable energy (ME) content of foliage from the tannin containing tree species, Pistica lentiscus, Arbutus andrachne and Juniperus communis. The amount of gas produced when the foliage was incubated with buffered rumen fluid, was determined after 0, 3, 6, 12, 24, 48, 72 and $96 \mathrm{~h}$ of incubation in the presence of PEG at inclusions rates of 15, 30, 60 and $90 \mathrm{mg}$ and in the absence of PEG. Their kinetics were described using the equation $\mathrm{p}=\mathrm{a}+\mathrm{b}\left(1-\mathrm{e}^{\mathrm{ct}}\right)$. Addition of PEG resulted in an increased gas production at almost all incubation times in all tree species. However species showed variable responses. After $3 \mathrm{~h}$ of incubation the PEG addition showed no significant effect on gas production when the foliage from $A$. andrachne was incubated, but had a significant effect on gas production as duration of incubation extended. The increase in gas production in response to increased levels of PEG inclusion was linear for P. lentiscus and J. communis. However, when the PEG inclusion rates exceeded $60 \mathrm{mg}$ there was no significant increase in gas production when A. andrachne was incubated. The estimated parameters such as gas production rate(c) and gas production (a) from the immediately soluble fraction were not affected by the level PEG treatment, except that PEG addition at $90 \mathrm{mg}$ had a significant effect on the gas production (a) from immediately soluble fraction of leaves of $J$. communis. Gas production (b) from the insoluble fraction (mL) and potential gas production $(\mathrm{a}+\mathrm{b})$, OMD and ME of tree leaves increased significantly with increasing levels of PEG addition. However, when PEG inclusion exceeded $60 \mathrm{mg}$ these parameters showed no significant increase when leaves from $A$. andrachne were incubated. Although the mean increase in OMD per mg PEG supplementation was 0.131 digestibility units, the increase in ME per mg PEG supplementation was 0.0201 ME units. The elevated levels of gas produced, and increased OMD and ME estimates with the inclusion of PEG demonstrated the negative effect of tannins in foliage on digestibility.
\end{abstract}

Keywords: Tree leaves, condensed tannin, polyethylene glycol, in vitro gas production, digestibility

\#Corresponding author. E-mail: akamalak@ksu.edu.tr

\section{Introduction}

Trees and shrubs have been used for generations as multipurpose resources in many parts of the world (Smith, 1992). Tree foliage is an important component of diets for goats, cattle, deer, game and sheep (Holechek, 1984; Papachristou \& Nastis, 1996) and plays an important role in the nutrition of herbivores in areas where few or no alternatives are available (Meuret et al., 1990). Tannins are phenolic compounds which occur commonly in higher plants. They are heterogeneous in composition, and their chemical nature is not known in all cases (Barroso, 2001). Moderate levels of tannins may prevent bloat and increase the proportion of protein escaping ruminal degradation and thus increase the proportion of dietary amino acids that becomes available for digestion in the small intestine (Salunkhe et al., 1990). This could improve the utilization of the essential amino acids in a diet (Waghorn et al., 1987). However, the utilization of tree and shrub leaves by herbivores is restricted by anti-nutritional factors such as a high tannin content which defend or protect the plant against predation (Provenza, 1995). Tannins act within the digestive tract of animals by binding substrates that could have been digested (usually proteins, carbohydrate and lipids), inhibiting the action of digestive enzymes or exerting anti-microbial effects in the digestive tract (Scalbert, 1991). High 
levels of tannins in leaves restrict the nutrient utilization by herbivores and decrease voluntary food intake, nutrient digestibility and N retention (Kumar \& Vaithiyanathan, 1990; Silanikove et al., 1996).

Polyethylene glycol (PEG) can form a stable complex with tannins thereby preventing the binding between tannins and proteins (Bandran \& Jones, 1965). Therefore, PEG has been used widely to reduce the detrimental effect of condensed tannin (CT) in ruminant diets (Barry, 1989; Silanikove et al., 1994; Pritchard et al., 1998; Jones et al., 2000). However, PEG supplementation to diets containing tannins does not give a similar response with all forages due to differences in the chemical composition of the tannins in forages (Jones \& Palmer, 2000).

Leaves from tannin containing tree species, Arbutus andrachne, Pistica lentiscus and Juniperus communis have been used extensively to meet the nutrient requirements of ruminants in Turkey during the critical periods of the year when quality and quantity of pasture herbages are lacking. The objective of this study was to determine the effect of including PEG during the incubation of the foliage from these species in an in vitro gas production study and on some parameters of nutritive value, viz. organic matter digestibility (OMD) and metabolisable energy (ME) levels.

\section{Materials and Methods}

Leaves from A. andrachne, $P$. lentiscus and J. communis were harvested in August in the vicinity of the city Kahramanmaras in the south of Turkey. The area is located at an altitude of $630 \mathrm{~m}$ above sea level. The mean annual rainfall and temperature are $857.5 \mathrm{~mm}$ and $16.2^{\circ} \mathrm{C}$, respectively. Leaves were handharvested from at least 10 different trees from each species within three sub-plots of $20 \mathrm{x} 20 \mathrm{~m}$ and ovendried at $60^{\circ} \mathrm{C}$ for $48 \mathrm{~h}$ (Abdulrazak et al., 2000).

All chemical analyses were carried out in triplicate. Dry matter (DM) content was determined by drying the samples at $105{ }^{\circ} \mathrm{C}$ overnight and ash content by igniting the dry sample in a muffle furnace at $525{ }^{\circ} \mathrm{C}$ for $8 \mathrm{~h}$. Nitrogen (N) content was measured by the Kjeldahl method (AOAC, 1990) to calculate crude protein (CP) as $\mathrm{N} \times$ 6.25. Acid detergent fibre (ADF) levels of the leaves were determined, using the method of Van Soest et al. (1991). Total CT, bound CT and soluble CT were determined by the butanol-HCl method, as described by Makkar et al. (1995). Mimosa tannin (MT; Hodgson Chemicals Ltd. London, UK) was used as an external standard.

Forage samples, milled through a $1 \mathrm{~mm}$ sieve, were incubated in buffered rumen fluid in calibrated glass syringes, according to the in vitro gas production procedure of Menke \& Steingass (1988). Rumen fluid was obtained from three fistulated sheep fed twice daily on a diet containing lucerne hay (60\%) and a concentrate (40\%). A foliage sample of $0.2 \mathrm{~g}$ DM was weighed in triplicate in the calibrated glass syringes of $100 \mathrm{~mL}$ in the presence of 0 (control without PEG) and 15, 30, 60 and $90 \mathrm{mg}$ PEG (MW 8000). The syringes were prewarmed at $39{ }^{\circ} \mathrm{C}$ before $30 \mathrm{~mL}$ of a rumen fluid-buffer mixture (at a ratio of $1: 2$ ) was injected into each syringe followed by incubation in a water-bath at $39^{\circ} \mathrm{C}$. Readings of gas production were recorded before incubation (0) and after 3, 6, 12, 24, 48, 72 and $96 \mathrm{~h}$ of incubation. Total gas values were corrected for a blank incubation. Cumulative gas production data were fitted to the exponential equation:

$$
\mathrm{p}=\mathrm{a}+\mathrm{b}\left(1-\mathrm{e}^{-\mathrm{ct}}\right) \text { (Ørskov \& McDonald, 1979) }
$$

where $\mathrm{p}$ is the gas production at time $\mathrm{t}$; $\mathrm{a}$ is the gas production from the immediately soluble fraction $(\mathrm{mL})$; $\mathrm{b}$ the gas production from the insoluble fraction $(\mathrm{mL})$; $c$ the gas production rate constant; $\mathrm{a}+\mathrm{b}=$ the potential gas production $(\mathrm{mL}) ; \mathrm{t}=$ incubation time $(\mathrm{h})$.

Metabolisable energy content of tree leaves was calculated using the equation of Menke et al. (1979):

$\mathrm{ME}(\mathrm{MJ} / \mathrm{kg} \mathrm{DM})=2.20+0.136 \mathrm{GP}+0.057 \mathrm{CP}+0.0029 \mathrm{CP}^{2}$

where $\mathrm{GP}=24 \mathrm{~h}$ net gas production $(\mathrm{mL} / 200 \mathrm{mg})$; $\mathrm{CP}=$ crude protein.

The OMD of the leaves was calculated using the equation of Menke et al. (1979):

OMD $(\%)=14.88+0.889 \mathrm{GP}+0.45 \mathrm{CP}+0.0651 \mathrm{XA}$

where XA is the ash content (\%).

One-way analysis of variance (ANOVA) was carried out to determine the effect of PEG treatment on in vitro gas production kinetics, using the General Linear Model (GLM) of Statistica for Windows (1993). Significance differences between individual means were identified using Tukey's multiple range test (Pearse \& Hartley, 1966). Mean differences were considered significant at $\mathrm{P}<0.05$. Standard errors of means were 
calculated from the residual mean square in the analysis of variance. A simple regression analysis was used to establish the relationship between the dose of PEG supplementation and OMD or ME.

\section{Results}

The proximate chemical composition and CT concentrations of the foliage from the tree species are presented in Table 1. Generally, considerable variations were recorded between species in terms of chemical compositions. The CP levels of the leaves ranged from 57.3 to $102.4 \mathrm{~g} / \mathrm{kg} \mathrm{DM}$. The ash content ranged from 57.3 to $75.3 \mathrm{~g} / \mathrm{kg}$ DM and ADF concentrations from 318.5 to $342.1 \mathrm{~g} / \mathrm{kg}$ DM.

Table 1 Mean chemical composition (g/kg DM) of leaves from three different tree species

\begin{tabular}{lccccc}
\hline & \multicolumn{3}{c}{ Tree species } & \multirow{2}{*}{ s.e.m. } & \multirow{2}{*}{$\mathrm{P}$} \\
\cline { 2 - 4 } & Arbutus andrachne & Pistica lentiscus & Juniperus communis & & \\
\hline Dry matter & $962.3^{\mathrm{b}}$ & $949.6^{\mathrm{a}}$ & $962.3^{\mathrm{b}}$ & 1.599 & $* * *$ \\
Ash & $68.5^{\mathrm{b}}$ & $57.3^{\mathrm{a}}$ & $75.3^{\mathrm{c}}$ & 0.604 & $* * *$ \\
Crude protein & $74.1^{\mathrm{a}}$ & $97.2^{\mathrm{b}}$ & $102.4^{\mathrm{c}}$ & 0.408 & $* * *$ \\
Acid detergent fibre & $332.7^{\mathrm{ab}}$ & $318.5^{\mathrm{a}}$ & $342.1^{\mathrm{b}}$ & 4.255 & $*$ \\
Total condensed tannin & $136.2^{\mathrm{a}}$ & $163.3^{\mathrm{b}}$ & $187.5^{\mathrm{c}}$ & 2.948 & $* * *$ \\
Bound condensed tannin & $36.4^{\mathrm{b}}$ & $28.4^{\mathrm{a}}$ & $165.7^{\mathrm{c}}$ & 1.547 & $* * *$ \\
Soluble condensed tannin & $100.3^{\mathrm{b}}$ & $132.2^{\mathrm{c}}$ & $22.4^{\mathrm{a}}$ & 0.759 & $* * *$ \\
\hline
\end{tabular}

${ }^{a b c}$ Row means with common superscripts do not differ $(\mathrm{P}>0.05)$; s.e.m. - standard error of mean

$*=\mathrm{P}<0.05 ; * * *=\mathrm{P}<0.001$

Table 2 The effect of polyethylene glycol (PEG) on in vitro gas production (mL) of foliage from Arbutus andrachne, Pistica lentiscus, Juniperus communis when incubated with buffered rumen fluid

\begin{tabular}{|c|c|c|c|c|c|c|c|}
\hline \multirow{2}{*}{$\begin{array}{c}\text { Duration of } \\
\text { incubation (h) }\end{array}$} & \multicolumn{5}{|c|}{ PEG inclusion rate (mg) } & \multirow{2}{*}{ s.e.m. } & \multirow{2}{*}{$\mathrm{P}$} \\
\hline & 0 & 15 & 30 & 60 & 90 & & \\
\hline \multicolumn{8}{|l|}{ A. andrachne } \\
\hline 3 & 20.7 & 22.0 & 23.0 & 23.0 & 23.1 & 0.545 & NS \\
\hline 6 & $29.5^{\mathrm{a}}$ & $33.0^{\mathrm{b}}$ & $34.8^{\mathrm{bc}}$ & $35.7^{c}$ & $36.3^{c}$ & 0.523 & $* * *$ \\
\hline 12 & $39.2^{\mathrm{a}}$ & $43.3^{b}$ & $45.5^{b c}$ & $47.8^{\mathrm{cd}}$ & $48.7^{d}$ & 0.610 & $* * *$ \\
\hline 24 & $44.7^{\mathrm{a}}$ & $50.7^{\mathrm{b}}$ & $53.7^{c}$ & $57.8^{\mathrm{d}}$ & $59.7^{d}$ & 0.614 & $* * *$ \\
\hline 48 & $52.2^{\mathrm{a}}$ & $58.0^{\mathrm{b}}$ & $61.7^{c}$ & $64.7^{\mathrm{d}}$ & $67.0^{\mathrm{d}}$ & 0.591 & $* * *$ \\
\hline 72 & $56.8^{\mathrm{a}}$ & $62.5^{b}$ & $66.3^{c}$ & $70.2^{d}$ & $71.8^{\mathrm{d}}$ & 0.636 & $* * *$ \\
\hline 96 & $61.2^{\mathrm{a}}$ & $65.3^{b}$ & $69.0^{\mathrm{bc}}$ & $72.2^{\mathrm{cd}}$ & $73.8^{d}$ & 0.799 & $* * *$ \\
\hline \multicolumn{8}{|l|}{ P. lentiscus } \\
\hline 3 & $23.5^{\mathrm{a}}$ & $24.5^{\mathrm{ab}}$ & $26.3^{c}$ & $27.2^{\mathrm{cd}}$ & $28.3^{d}$ & 0.428 & $* * *$ \\
\hline 6 & $32.0^{\mathrm{a}}$ & $32.5^{\mathrm{a}}$ & $37.2^{b}$ & $39.6^{c}$ & $40.7^{\mathrm{c}}$ & 0.288 & $* * *$ \\
\hline 12 & $41.0^{\mathrm{a}}$ & $43.8^{b}$ & $45.8^{\mathrm{bc}}$ & $48.3^{c}$ & $52.2^{\mathrm{d}}$ & 0.623 & $* * *$ \\
\hline 24 & $50.0^{\mathrm{a}}$ & $53.7^{\mathrm{b}}$ & $55.0^{\mathrm{bc}}$ & $56.8^{\mathrm{c}}$ & $62.5^{\mathrm{d}}$ & 0.401 & $* * *$ \\
\hline 48 & $54.0^{\mathrm{a}}$ & $57.3^{b}$ & $62.5^{c}$ & $65.3^{c}$ & $70.7^{d}$ & 0.683 & $* * *$ \\
\hline 72 & $61.0^{\mathrm{a}}$ & $63.3^{\mathrm{a}}$ & $67.9^{b}$ & $70.2^{b}$ & $76.2^{\mathrm{c}}$ & 0.521 & $* * *$ \\
\hline 96 & $64.3^{\mathrm{a}}$ & $66.3^{\mathrm{a}}$ & $71.7^{b}$ & $73.3^{b}$ & $80.2^{\mathrm{c}}$ & 0.542 & $* * *$ \\
\hline \multicolumn{8}{|l|}{ J. communis } \\
\hline 3 & $21.3^{\mathrm{a}}$ & $22.8^{\mathrm{ab}}$ & $23.5^{\mathrm{ab}}$ & $24.8^{b}$ & $28.2^{\mathrm{c}}$ & 0.505 & $* * *$ \\
\hline 6 & $29.2^{\mathrm{a}}$ & $30.5^{\mathrm{a}}$ & $34.2^{b}$ & $35.7^{\mathrm{bc}}$ & $38.2^{c}$ & 0.552 & $* * *$ \\
\hline 12 & $38.8^{\mathrm{a}}$ & $42.0^{\mathrm{a}}$ & $45.8^{b}$ & $51.2^{\mathrm{c}}$ & $51.8^{\mathrm{c}}$ & 0.687 & $* * *$ \\
\hline 24 & $48.8^{\mathrm{a}}$ & $51.2^{b}$ & $54.3^{c}$ & $58.3^{d}$ & $63.7^{\mathrm{e}}$ & 0.401 & $* * *$ \\
\hline 48 & $49.5^{\mathrm{a}}$ & $54.7^{b}$ & $60.0^{c}$ & $65.0^{\mathrm{d}}$ & $70.5^{e}$ & 0.415 & $* * *$ \\
\hline 72 & $54.7^{\mathrm{a}}$ & $60.2^{b}$ & $65.0^{c}$ & $68.7^{\mathrm{d}}$ & $75.7^{\mathrm{e}}$ & 0.394 & $* * *$ \\
\hline 96 & $59.8^{\mathrm{a}}$ & $63.3^{b}$ & $68.4^{c}$ & $72.5^{d}$ & $78.2^{\mathrm{e}}$ & 0.545 & $* * *$ \\
\hline
\end{tabular}

\footnotetext{
${ }^{a b c}$ Row means with common superscripts do not differ $(\mathrm{P}>0.05)$; s.e.m. - standard error of mean; $* * *=\mathrm{P}<0.001 ; \mathrm{NS}-$ non significant $(\mathrm{P}>0.05)$
} 
Addition of PEG resulted in increased gas production during almost all incubation times in all tree species used in this experiment (Table 2). However, variable responses between tree species were recorded. After $3 \mathrm{~h}$ of incubation the PEG addition had no significant $(\mathrm{P}>0.05)$ effect on gas production of A. andrachne but the addition of PEG had a significant effect $(\mathrm{P}<0.001)$ on gas production as incubation times increased. Positive linear responses were recorded between level of PEG inclusion and volume of gas produced when foliage from $P$. lentiscus and $J$. communis was incubated. When PEG inclusion rate exceeded $60 \mathrm{mg}$, no significant $(\mathrm{P}>0.05)$ increase in gas production was recorded for the incubation of foliage from A. andrachne.

After $96 \mathrm{~h}$ of incubation the increases in gas production above the control due to the inclusion of 90 mg PEG were 20.6, 24.7 and 30.8\% for A. andrachne, P. lentiscus and J. communis, respectively (Table 2). The effects of PEG on gas production kinetics, OMD and ME levels of P. lentiscus, A. andrachne and $J$. communis are presented in Table 3. PEG inclusion had no effect $(\mathrm{P}>0.05)$ on gas production rates(c), nor on gas production (a) from the immediately soluble fraction, except that PEG addition at $90 \mathrm{mg}$ affected the gas production (a) significantly $(\mathrm{P}<0.001)$ in the case of the immediately soluble fraction of leaves of J. communis.

Table 3 The effect of polyethylene glycol (PEG) supplementation on gas production kinetics, organic matter digestibility (OMD) and metabolisable energy (ME) of foliage from Arbutus andrachne, Pistica lentiscus and Juniperus communis

\begin{tabular}{|c|c|c|c|c|c|c|c|}
\hline & \multicolumn{5}{|c|}{ PEG inclusion rate (mg) } & \multirow{2}{*}{ s.e.m. } & \multirow{2}{*}{$\mathrm{P}$} \\
\hline & 0 & 15 & 30 & 60 & 90 & & \\
\hline \multicolumn{8}{|l|}{ A. andrachne } \\
\hline c & 0.099 & 0.107 & 0.106 & 0.104 & 0.099 & 0.003 & NS \\
\hline $\mathrm{a}$ & 3.4 & 2.9 & 3.0 & 2.7 & 2.7 & 0.317 & NS \\
\hline $\mathrm{b}$ & $52.2^{\mathrm{a}}$ & $57.7^{\mathrm{b}}$ & $60.8^{c}$ & $65.3^{d}$ & $67.4^{\mathrm{d}}$ & 0.660 & $* * *$ \\
\hline$a+b$ & $55.6^{\mathrm{a}}$ & $60.7^{\mathrm{b}}$ & $63.8^{c}$ & $68.0^{\mathrm{d}}$ & $70.1^{\mathrm{d}}$ & 0.635 & $* * *$ \\
\hline OMD (\%) & $56.0^{\mathrm{a}}$ & $61.4^{\mathrm{b}}$ & $64.0^{\mathrm{c}}$ & $67.7^{\mathrm{d}}$ & $69.4^{\mathrm{d}}$ & 0.545 & $* * *$ \\
\hline $\mathrm{ME}(\mathrm{MJ} / \mathrm{kg} \mathrm{DM})$ & $8.9^{\mathrm{a}}$ & $9.7^{b}$ & $10.1^{\mathrm{c}}$ & $10.6^{\mathrm{d}}$ & $10.9^{d}$ & 0.082 & $* * *$ \\
\hline \multicolumn{8}{|l|}{ P. lentiscus } \\
\hline c & 0.106 & 0.110 & 0.107 & 0.114 & 0.106 & 0.003 & NS \\
\hline $\mathrm{a}$ & 3.6 & 3.2 & 4.2 & 3.9 & 4.1 & 0.295 & NS \\
\hline $\mathrm{b}$ & $55.1^{\mathrm{a}}$ & $58.2^{\mathrm{b}}$ & $61.6^{\mathrm{c}}$ & $63.9^{d}$ & $70.1^{\mathrm{e}}$ & 0.431 & $* * *$ \\
\hline$a+b$ & $58.7^{\mathrm{a}}$ & $61.4^{\mathrm{b}}$ & $65.8^{\mathrm{c}}$ & $67.8^{\mathrm{c}}$ & $74.2^{d}$ & 0.466 & $* * *$ \\
\hline OMD (\%) & $61.2^{\mathrm{a}}$ & $64.4^{\mathrm{b}}$ & $65.6^{c}$ & $67.3^{c}$ & $72.3^{d}$ & 0.356 & $* * *$ \\
\hline ME (MJ/kg DM) & $10.0^{\mathrm{a}}$ & $10.5^{\mathrm{b}}$ & $10.6^{c}$ & $10.9^{c}$ & $11.6^{\mathrm{d}}$ & 0.053 & $* * *$ \\
\hline \multicolumn{8}{|l|}{ J. communis } \\
\hline C & 0.114 & 0.109 & 0.110 & 0.116 & 0.105 & 0.003 & NS \\
\hline $\mathrm{a}$ & $2.4^{\mathrm{a}}$ & $2.9^{\mathrm{a}}$ & $2.7^{\mathrm{a}}$ & $2.2^{\mathrm{a}}$ & $3.8^{\mathrm{b}}$ & 0.156 & $* * *$ \\
\hline $\mathrm{b}$ & $51.7^{\mathrm{a}}$ & $55.7^{\mathrm{b}}$ & $60.6^{c}$ & $65.3^{d}$ & $70.0^{\mathrm{e}}$ & 0.356 & $* * *$ \\
\hline$a+b$ & $54.2^{\mathrm{a}}$ & $58.6^{\mathrm{b}}$ & $63.3^{c}$ & $67.5^{\mathrm{d}}$ & $73.8^{\mathrm{e}}$ & 0.387 & $* * *$ \\
\hline OMD (\%) & $59.4^{\mathrm{a}}$ & $61.5^{b}$ & $64.3^{c}$ & $67.9^{\mathrm{d}}$ & $72.6^{\mathrm{e}}$ & 0.356 & $* * *$ \\
\hline ME (MJ/kg DM) & $9.3^{\mathrm{a}}$ & $9.6^{\mathrm{b}}$ & $10.0^{\mathrm{c}}$ & $10.5^{\mathrm{d}}$ & $11.3^{\mathrm{e}}$ & 0.054 & $* * *$ \\
\hline
\end{tabular}

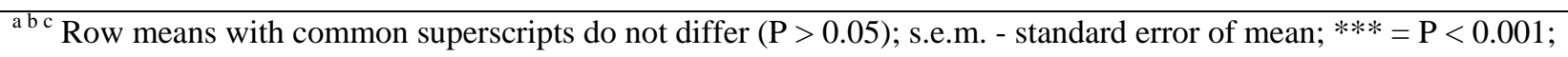
NS - non significant $(\mathrm{P}>0.05)$

c - gas production rate (\%); a - gas production $(\mathrm{mL})$ from quickly soluble fraction; $\mathrm{b}$ - gas production (mL) from the insoluble fraction; $\mathrm{a}+\mathrm{b}$ - potential gas production $(\mathrm{mL})$ 
Gas production $(\mathrm{mL})$ from the insoluble fraction $(\mathrm{b})$ and potential gas production $(\mathrm{a}+\mathrm{b})$ increased with increasing inclusion rates of PEG (Table 3). However, there were no significant $(P>0.05)$ increases in the same parameters of leaves from $A$. andrachne when the PEG inclusion rate exceeded $60 \mathrm{mg}$.

The PEG addition also increased the OMD and ME values of tree leaves with increasing levels of PEG addition. The increases in OMD values of leaves from A. andrachne, P. lentiscus and J. communis were 13.3, 11.1 and 13.2 digestibility units, respectively when PEG inclusion rate was $90 \mathrm{mg}$ while the increases in ME values of leaves were 2.4, 1.67 and 2.0 ME units, respectively.

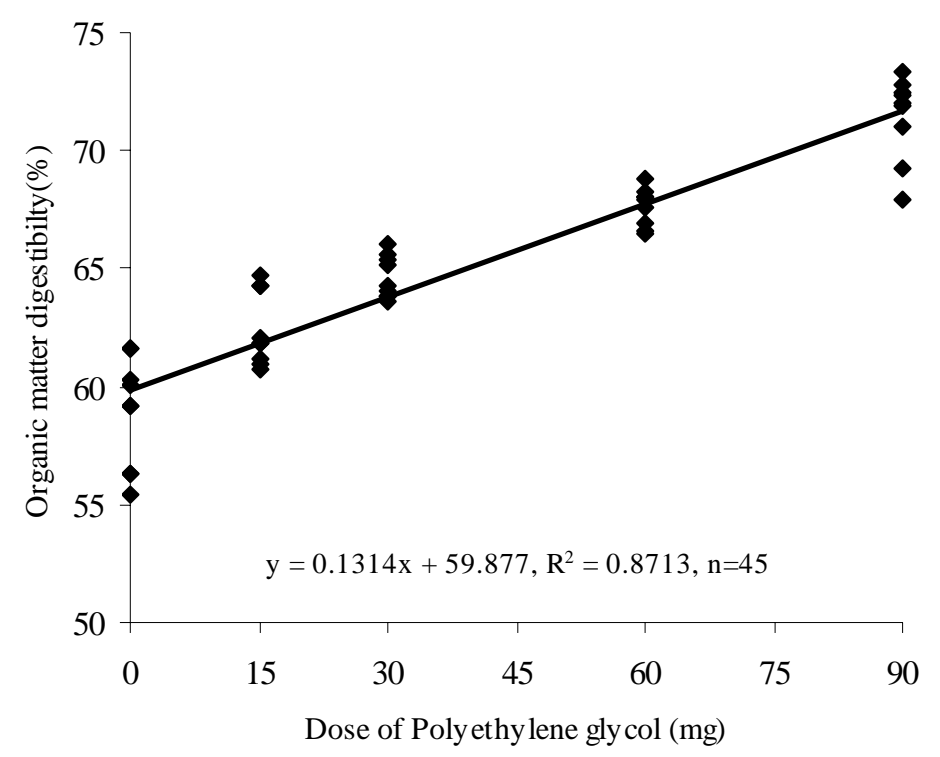

Figure 1 The relationship between dose of PEG supplementation and organic matter digestibility of foliage from the three tree species

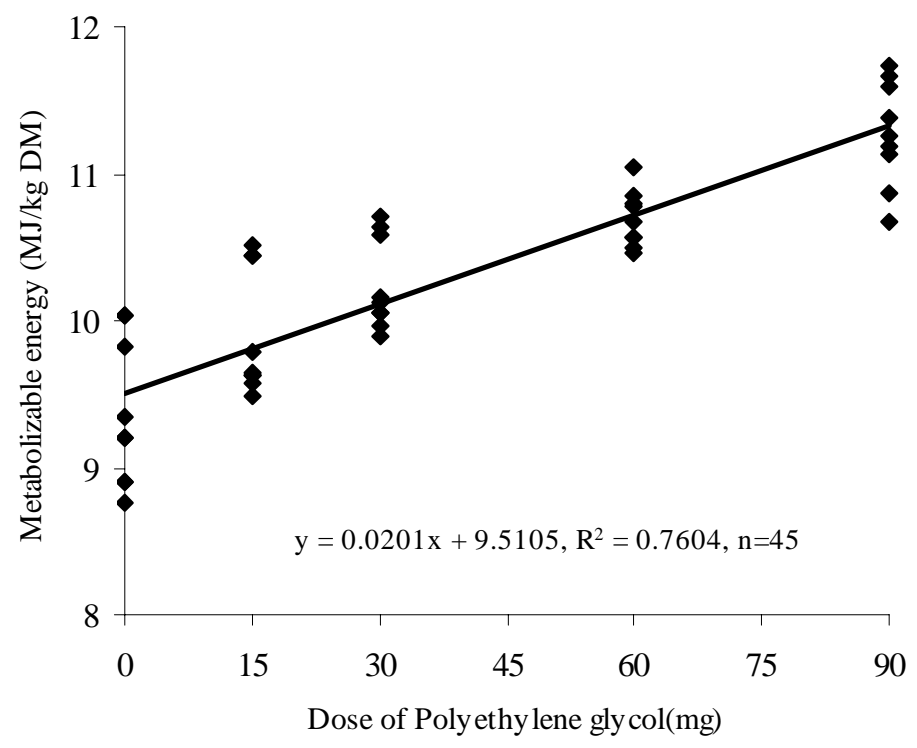

Figure 2 The relationship between dose of PEG supplementation and metabolisable energy of foliage from the three tree species 
The relationships between level of PEG and OMD or ME values are given in Figures 1 and 2. The OMD of tannin containing tree leaves increased with increasing levels of PEG. The mean increase in OMD per mg PEG supplementation was 0.131 digestibility units. The ME of tannin containing tree leaves also increased with increasing levels of PEG. The mean increase in ME per mg PEG supplementation was 0.0201 ME units.

\section{Discussion}

Leaves from P. lentiscus, A. andrachne and J. communis had low CP concentrations compared to Acacia species (Rubanza et al., 2005). Therefore, herbivores consuming these leaves should receive supplemental protein from other sources. The chemical composition of $P$. lentiscus was similar to that reported by Decandia et al. (2000). However, the total CT content of P. lentiscus was lower than that reported by Decandia et al. (2000) and Silanikove et al. (1996).

Optimal utilization of CP in browsable leaves could be limited by high concentrations of CT (50 g/kg DM) due to chemical complexes that are formed between CT and dietary nutrients. The mechanism of dietary effects of tannins might be understood by their ability to form complexes with proteins. Tannins may form a less digestible complex with dietary proteins and may bind and inhibit the actions of endogenous protein, such as digestive enzymes (Kumar \& Singh, 1984). Tannin can adversely affect microbial and enzyme activities in the digestive tract of ruminants (Singleton, 1981; Lohan et al., 1983; Barry \& Duncan, 1984; Makkar et al., 1989). In tree leaves significant amounts of the tannins are present in the NDF and ADF fractions, where they are tightly bound to the cell wall and cell protein, and seem to be involved in suppressing digestibility (Reed et al., 1990). In ruminants, dietary CT levels of between $2-3 \%$ have been shown to exert beneficial effects in the form of a reduction of wasteful protein degradation in the rumen through the forming of non-degradable protein-tannin complexes (Barry, 1987).

Some studies clearly showed that PEG supplementation to diets containing tannins increased the volume of gas produced and total volatile fatty acid production (Getachew et al., 2001; 2002; Seresinhe \& Iben, 2003). The increase in the gas production in the presence of PEG is suggested to be due to an increase in the available nutrients to rumen microorganisms, especially N. McSweeney et al. (1999) showed that the addition of PEG caused a significant and marked increase in the rate and extent of ammonia production in the rumen. It has been shown also that the supplementation of PEG at a level of 25 or $50 \mathrm{~g}$ per day to goat fed lentiks leaves and concentrate markedly increased in vivo DM, OM and protein digestibility. Although the improvements in the digestibility of DM and OM were small, the improvement in protein digestibility ranged from 25.8 to 34 digestibility units (Decandia et al., 2000).

Leaves of $P$. lentiscus, A. andrachne and $J$. communis did not show similar responses to PEG inclusion during the in vitro incubation study. This is possibly due to differences in the chemical composition of the tannins they contained. The CT content of $A$. andrachne was considerably lower than that of $P$. lentiscus and $J$. communis (Table 3). One possible reason why the gas produced when A. andrachne was incubated did not continue to increase when PEG inclusion rates exceeded $60 \mathrm{mg}$, is that all available CT was attached to PEG at PEG inclusion rates below $60 \mathrm{mg}$. After $96 \mathrm{~h}$ of incubation and at a PEG inclusion rate of $90 \mathrm{mg}$ the increases of gas production above the control of incubated $A$. andrachne, P. lentiscus and J. communis foliage were 12.6, 15.9 and $18.4 \mathrm{~mL}$, respectively. Vitti et al. (2005) found that PEG inclusion had a significant effect on total gas production. After $24 \mathrm{~h}$ of incubation increases in gas production of 9.4, 0.0, 6.6 and 40.3\% above a control containing no PEG were recorded for coastcross hay, Cajanus, Leucaena and Sesbania, respectively (Vitti et al., 2005). In the present experiment the increases above the control in total gas production due to PEG inclusion were 20.6, 24.7 and $30.8 \%$ for P. lentiscus, A. andrachne and J. communis, respectively. This is in agreement with findings of Rubanza et al. (2005) that foliage from Acacia species gave different responses to PEG inclusion.

When PEG was included, the increases in OMD values above the control were 13.4, 11.1 and 13.2 digestibility units for $A$. andrachne, P. lentiscus and $J$. communis, respectively. This is in agreement with the findings of Rubanza et al. (2005) who reported that the increase in OMD of leaves from Acacia species due to PEG (100 mg) ranged from 10.1 and 49.2 digestibility units. Similarly, Rubanza et al. (2003) reported that such an increase in OMD of leaves from browse fodders ranged from 2.1 to 10.2 digestibility units. 
The inclusion of PEG increased the ME values of A. andrachne, P. lentiscus and J. communis by 2, 1.6 and 2 ME units above that of the controls, respectively. This result is in agreement with the findings of Rubanza et al. (2005) who reported that the increase in ME of leaves from Acacia species due to PEG (100 mg) ranged from 2.0 to 7.1 ME units. Similarly, Rubanza et al. (2003) reported that PEG inclusion increased the ME values of leaves from browse fodders from 0.33 to $1.56 \mathrm{ME}$ units.

It has been reported that the reduction in CP digestibility is a consequence of CT binding to dietary constituents and bacteria, and that CT also reduces attachment of bacteria to plant particles (McAllister et al., 1994). Thus, an improvement in digestibility could be due to both increased rates and extent of digestion in the rumen when PEG was added to a diet containing CT (Waghorn et al., 1994). The effect of PEG also depends on the level of proteins in diet. Proteins mimic the effect of PEG. The higher the level of protein in a substrate, the lesser is the effect of PEG (Makkar \& Becker, 1996). The level of CP in the foliage of Mediterranean bushes is often lower than $100 \mathrm{mg} / \mathrm{kg}$ DM (Leclerc, 1984) with decreasing trends from spring to the following autumn.

The improvement in gas production, OMD and ME due to PEG inclusion emphasizes the negative effect of tannins on digestibility. PEG, a non-nutritive synthetic polymer, has a high affinity to tannins and makes tannins inert by forming tannin-PEG complexes (Makkar et al., 1995). PEG can also liberate protein from the preformed tannin-protein complexes (Barry \& Manley, 1986).

It has been shown that PEG can be added to tannin containing plant material in in vitro fermentation systems to demonstrate the nutritional importance of tannins on OM digestibility and to measure the nutritive value of the forage after neutralization (Makkar et al., 1995; McSweeney et al., 1999; Getachew et al., 2001). However, there is a lack of information about the feasibility of using PEG in tannin rich diets for ruminants. It is estimated that $15 \mathrm{mg}$ PEG/tube is required to neutralise $75 \mathrm{~g} \mathrm{CT/g}$ sample. In other words, 75 g PEG must be supplemented in the diet per day to obtain a 4 - 5 units improvement in OMD. Therefore, it is possible to estimate the feasibility of using PEG in practice by comparing the value of $4-5$ unit improvement in OMD and the extra cost of $75 \mathrm{~g} / \mathrm{kg}$ feed per day. Assuming a DM intake of $1 \mathrm{~kg} / \mathrm{day}$, the improvement in OMD corresponds to a feeding of $c a .50 \mathrm{~g}$ barley/day. This is likely to be economical at a PEG inclusion of $75 \mathrm{~g}$ in the diet per day since the cost of including PEG per day is US\$1.22/kg feed. The PEG supplementation to improve the nutritive value of tannin containing tree leaves should be further analyzed in detail to ascertain whether or not it is economical.

\section{Conclusion}

The PEG inclusion had a significant effect on the gas production and estimated parameters such as OMD and ME of tree leaves. The PEG inclusion increased the gas production, OMD and ME contents of leaves. The improvement in gas production, OMD and ME with PEG emphasizes the negative effect of tannins on digestibility. However tree species showed variable responses on increase in gas production and estimated parameters such as OMD and ME.

The improvement in nutritive value of leaves due to PEG supplementation seems to be lower than expected. However, before large scale implementation, further investigations are required to determine the effect of condensed tannin on voluntary food intake, animal performance and the profitability of the supplementation since some of tree leaves have considerable high condensed tannin content. The success of PEG supplementation will depend on cost: benefit ratio.

\section{References}

Abdulrazak, S.A., Fujihara, T., Ondilek, J.K. \& Ørskov, E.R., 2000. Nutritive evaluation of some Acacia tree leaves from Kenya. Anim. Feed Sci. Technol. 85, 89-98.

AOAC, 1990. Official Method of Analysis. (15th. ed.). Association of Official Analytical Chemist, Washington, D.C., USA.

Bandran, A.M. \& Jones, D.E., 1965. Polyethylene glycols-tannin interaction in extracting enzyme. Nature 206, 622-623.

Barroso, F.G., Martinez, T.F., Paz, T., Parra, A. \& Alarcon, F.J., 2001. Tannin content of grazing plants of southern Spanish arid lands. J. Arid Envir. 49, 301-314. 
Barry, T.N., 1987. Secondary compounds of forages. In: The Nutrition of Herbivores. Eds. Hacker, J.B. \& Ternouth, J.H., Academic Press. Sydney, Australia. pp. 91-120.

Barry, T.N., 1989. Condensed tannins: their role in ruminant protein and carbohydrate digestion and possible effects upon the rumen ecosystem. In: The Roles of Protozoa and Fungi in Ruminant Digestion. Eds. Nolan, J.V., Leng, R.A. \& Demeyer, D.J., Penembul Books, Armidale, NSW, Australia.

Barry, T.N. \& Duncan, S.J., 1984. The role of condensed tannins in the nutritional value of Lotus pedunculatus for sheep. I. Voluntary intake. J. AOAC. 65, 496-497.

Barry, T.N., Manley, T.R. \& Duncan, S.J., 1986. The role of condensed tannins in the nutritional value of Lotus pedunculatus for sheep. 4. Site of carbohydrate and protein digestion as influenced by dietary reactive tannin concentration. Br. J. Nutr. 55, 123-137.

Decandia, M., Sitzia, M., Cabiddu, A., Kababya, D. \& Molle, G., 2000. The use of polyethylene glycol to reduce the anti-nutritional effects of tannins in goats fed woody species. Small Rumin. Res. 38, 157164.

Getachew, G., Makkar, H.P.S. \& Becker, K., 2001. Method of polyethylene glycol application to tannincontaining browses to improve microbial fermentation and efficiency of microbial protein synthesis from tannin-containing browses. Anim. Feed Sci. Technol. 92, 51-57.

Getachew, G., Makkar, H.P.S. \& Becker, K., 2002. Tropical browses: contents of phenolic compounds, in vitro gas production and stoichiometric relationship between short chain fatty acid and in vitro gas production. J. Agric. Sci., Camb. 139, 341-352.

Holechek, J.L., 1984. Comparative contribution of grasses, forbs, and shrubs to the nutrition range ungulates. Rangelands 6, 261-263.

Jones, R.J. \& Palmer, B., 2000. In vitro digestion studies using 14C-labelled polyethylene glycol (PEG) 4000: comparison of six tanniniferous shrub legumes and the grass Panicum maxicum. Anim. Feed Sci. Technol. 86, 215-221.

Jones, R.J., Meyer J.H.F., Bechaz, F.M. \& Stoltz, M.A., 2000. An approach to screening potential pastures species for condensed tannin activity. Anim. Feed Sci. Technol. 85, 269-277.

Khazaal, K., Boza, J. \& Ørskov, E.R., 1994. Assessment of phenolics-related anti-nutritive effects in Mediterranean browse. A comparison between the use of the in vitro gas production technique with or without insoluble polyvinylpolypyrrolidone or nylon bag. Anim. Feed Sci. Technol. 49,133-149.

Kumar, R. \& Sing, M., 1984. Tannins: their adverse role in ruminant nutrition. J. Agric. Food Chem. 32, 447-453.

Kumar, R. \& Vaithiyanathan, S., 1990. Occurrence, nutritional significance and effect on animal productivity of tannins in tree leaves. Anim. Feed Sci. Technol. 30, 21-38.

Leclerc, B., 1984. Utilization of the Corsican maquis by goat and sheep. Acta Ecol. 5 (4), 383-406.

Lohan, O.P., Lall, D., Vaid, J. \& Negi, S.S., 1983. Utilization of oak tree fodder in cattle ration and fate of oak leaf tannins in the ruminant system. Indian J. Anim. Sci. 53, 1057-1063.

Makkar, H.P.S. \& Becker, K., 1996. A bioassay for tannins. In: Polyphenols Communications. Vol: 96. Proc. XVIII ${ }^{\text {th }}$ Int. Conf. on Polyphenols, Bordeaux, July 15-18. pp. 197-198.

Makkar, H.P.S., Blümmel, M. \& Becker, K., 1995. Formation of complexes between polyvinyl pyrrolidones or polyethylene glycols and their implication in gas production and true digestibility in vitro techniques. Br. J. Nutr. 73, 897-913.

Makkar, H.P.S., Singh, B. \& Negi, S.S., 1989. Relationship of rumen degradability with microbial colonization, cell wall constituents and tannin levels in some tree leaves. Anim. Prod. 49, 299-303.

McAllister, T.A., Bae, H.D., Jones, G.A. \& Cheng, K.J., 1994. Microbial attachment and feed digestion in the rumen. J. Anim. Sci. 72, 3004-3018.

McSweeney, C.S., Palmer, B., Bunch, R. \& Krause, D.O., 1999. In vitro quality assessment of tannincontaining tropical shrub legumes: protein and fibre digestion. Anim. Feed Sci. Technol. 82, 227-241.

Menke, H.H. \& Steingass, H., 1988. Estimation of the energetic feed value obtained from chemical analysis and in vitro gas production using rumen fluid. Anim. Res. Dev. 28, 7-55.

Menke, K.H., Raab, L., Salewski, A., Steingass, H., Fritzi, D. \& Schneider, W., 1979. The estimation of digestibility and metabolizable energy content of ruminant feedstuffs from the gas production when they incubated with rumen liquor in vitro. J. Agric. Sci., Camb. 92, 217-222. 
Meuret, M., Boza, J., Narjisse, N. \& Nastis, A., 1990. Evaluation and utilization of rangeland feeds by goats. In: Goat Nutrition, Ed. Morand-Fehr, P., PUDOC. Wageningen, The Netherlands. pp.161-170.

Ørskov, E.R. \& McDonald, P., 1979. The estimation of protein degradability in the rumen from incubation measurements weighed according to rate of passage. J. Agric. Sci., Camb. 92, 499-503.

Papachristou, T.G. \& Nastis, A.S., 1996. Influence of deciduous broadleaved woody species in goat nutrition during the dry season in Northern Greece. Small Rumin. Res. 20, 15-22.

Pearse, E.S. \& Hartley, H.O., 1966. Biometrica Tables for Statisticians, Vol. 1. Cambridge, University Press, UK.

Pritchard, D.A., Stocks, D.C., O’Sullivan, B.M., Martin, P.R., Hurwood, I.S. \& O’Rourke, P.K., 1998. The effect of polyethylene glycol (PEG) on wool growth and liveweight of sheep consuming a mulga (Acacia aneura) diet. Proc. Aust. Soc. Anim. Prod. 17, 290-293.

Provenza, F.D., 1995. Postingestive feedback as an elementary determinant of food selection and intake in ruminants. J. Rangl. Mgnt. 48, 2-17.

Reed, J.D., Soller, H. \& Wood, A., 1990. Fodder tree and straw diets for sheep: intake, growth, digestibility and the effect of phenolics on nitrogen utilization. Anim. Feed Sci. Technol. 30, 39-50.

Rubanza, C.D.K., Shem, M.N., Otsyina, R., Bakangesa, S.S., Ichinohe, T. \& Fujihara, T., 2005. Polyphenolics and tannins effect on in vitro digestibility of selected Acacia species leaves. Anim. Feed Sci. Technol. 119, 129-142.

Rubanza, C.D.K., Shem, M.N., Otsyina, R., Ichinohe, T. \& Fujihara, T., 2003. Nutritive evaluation of some browse tree legume foliages native to semi arid areas in western Tanzania. Asian-Aust. J. Anim. Sci. $16,1429-1437$.

Salunkhe, D.K., Chavan, J.K. \& Kadam, S.S., 1990. Dietary Tannins: Consequences and Remedies. Florida. CSC Press Inc. Boca Raton. pp. 113-146.

Scalbert, A., 1991. Antimicrobial properties of tannins. Phytochemistry 12, 3875-3883.

Seresinhe, T. \& Iben, C., 2003. In vitro quality assessment of two tropical shrub legumes in relation to their extractable tannins content. J. Anim. Physiol. Anim. Nutr. 87, 109-115.

Silanikove, N., Gilboa, N., Perevolotsky, Z. \& Nitsan, Z., 1996. Goats fed tannin containing leaves do not exhibit toxic syndromes. Small Rumin. Res. 21, 195-201.

Silanikove, N., Nitsan, Z. \& Perevolotski, A., 1994. Effect of a daily supplementation of polyethylene glycol on intake and digestion of tannin containing leaves (Ceratonia siliqua) by sheep. J. Agric. Food Chem. 42, 2844-2847.

Singleton, V.L., 1981. Naturally occurring food toxicants: Phenolic substances of plant origin common in foods. Adv. Food Res. 27, 149-242.

Smith, O.B., 1992. Fodder trees and fodder shrubs in range and farming systems in tropical humid Africa. In: Legume Trees and Other Fodder Trees as Protein Sources for Livestock. Eds. Speedy, A. \& Pugliese, P.L., FAO Animal Production and Health, Paper 102. pp. 43-60.

Stastica, 1993. Stastica for windows release 4.3, StatSoft, Inc. Tulsa, OK. USA.

Van Soest, P.J., Robertson, J.D. \& Lewis, B.A., 1991. Methods for dietary fiber, neutral detergent fiber and non-starch polysaccharides in relation to animal nutrition. J. Dairy Sci. 74, 3583-3597.

Vitti, D.M.S.S., Abdalla, A.L., Bueno, I.C.S., Silva Filho, Costa, C., Bueno, M.S., Nozella, E.F., Longo, C., Vieira, E.Q., Cabral Filho, S.L.S., Godoy, P.B. \& Mueller Harves, I., 2005. Do all tannins have similar nutritional effects? A comparison of three Brazilian fodder legumes. Anim. Feed Sci. Technol. 119, 345-361.

Waghorn, G.C., Shelton, I.D. \& McNabb, W.C., 1994. Effect of CT in Lotus pedunculatus on its nutritive value for sheep 1: non-nitrogenous aspects. J. Agric. Sci., Camb. 123, 99-107.

Waghorn, G.C., Ulyatt, M.J., John, A. \& Fisher, M.T., 1987. The effect of condensed tannins on site of digestion of amino acids and other nutrients in sheep fed on Lotus corniculatus L. Br. J. Nutr. 57, 115126. 